Botanical and Chemical

\section{Composition of Esophageal and Rumen Fistula Samples of Sheep ${ }^{1}$}

\author{
R. W. RICE, 1 D. R. CUNDY, \\ AND P. R. WEYERTS \\ Associate Professor and Research Assistants, \\ Animal Science Division, University of \\ Wyoming, Laramie.
}

\section{Highlight}

Bifistulated wethers (esophageal and rumen) were used to collect samples of the diet while grazing shortgrass native range. Rumen samples were obtained by grab sampling rumen contents. The rumens were not evacuated prior to sampling. The esophageal and rumen grab samples were different botanically. There were fewer forbs and more grasses found in rumen samples. The nitrogen content of rumen samples was higher than that of esophageal samples. Rumen samples were lower in in vitro dry matter digestibility than esophageal samples. Rumen grab samples cannot be expected to yield quantitative botanical information on grazing animals diet or on nitrogen content and dry matter digestibility.

The accurate determination of the chemical and botanical composition of the diet of grazing animals is essential for proper cvaluation and management of grazing lands. Many workers have examined the stomach contents of foraging animals to determine what the animals are eating (for review see Martin and Korschgen, 1963). In recent years the esophageal fistula has been used to obtain diet samples of grazing domestic livestock (for review see Van Dyne and Torell, 1964). Esophageal fistulated animals must be managed carefully and must be easily caught and handled for successful sample collection. This technique does not lend itself to wild herbivores where close management is not usually possible.

The purpose of this study was to compare the botanical and chemical composition of the diet of sheep as determined from rumen or esophageal samples obtained from grazing sheep.

\section{Procedure}

The study area was a native range located approximately $4 \mathrm{~km}$ west of Laramie, Wyoming. The vegetation was composed mainly of blue grama (Bouteloua gracilis) with native midgrasses such as western wheatgrass (Agropyron smithii), Sandberg bluegrass (Poa secunda), prairie junegrass (Koeleria cristata) and sedges (Carex spp.). The introduced grasses, crested wheatgrass (Agropyron cristatum) and smooth brome (Bromus inermis) were also

${ }^{1}$ Approved as Journal Paper No. 423 by the Director, Wyoming Agricultural Experiment Station. Received July 6, 1970; accepted for publication September 8, 1970. present. The forbs were vetches (Astragalus missouriensis and $A$. striatus), Foothill bladderpod (Lesquerella ludoviciana), Lewis flax (Linum lewisii) and scarlet globemallow (Sphaeralcea coccinea). The shrub species were a minor component and were fringed sagewort (Artemisia frigida), rabbitbrushes (Chrysothamnus nauseosus and viscidiflorus) and winter fat (Eurotia lanata) (Table 1).

Two bifistulated wethers (esophageal and rumen) were placcd on a two hectarc pasture in May and allowed to adjust to the area for two weeks. Rumen and esophageal samples were collected weekly from June 7 through August 22, 1968. For collections the animals were caught and the esophageal plugs removed. A bag was placed around the neck and the animals allowed to graze for approximately one hour. The animals were recaptured and esophageal samples collected. At the same time the rumen fistula plugs were removed and rumen contents sampled by obtaining ingesta from the top layer of rumen contents. A total of 18 esophageal and rumen samples were obtained. The samples were transported to the laboratory where they were rinsed with cold water and frozen.

Botanical analyses were accomplished by thawing the samples and spreading them evenly over a $28 \times 28 \mathrm{~cm}$ tray. The tray was placed on a peg board and a systematic point method followed for locating plant fragments to be identified. The method was similar to that described by Van Dyne and Heady (1965).

The csophagcal and rumen samples were dried at $60 \mathrm{C}$, ground through a 40 mesh screen and the digestibility estimated by an in vitro artificial rumen procedure (Tilley and Terry, 1963). The nitrogen in the samples was determined by the AOAC Kjeldahl procedure (1960).

Statistical analyses were by a paired t-test. Probabilities of $\mathrm{P}<.05$ were accepted as significant.

\section{Results and Discussion}

\section{Number of Points per Sample}

The number of points necessary to estimate the botanical composition of the diet has been examined by several investigators. Lesperance et al. (1960) read 100 points Harker et al. (1964) read 400 microscopic points per sample, and Van Dyne and Heady (1965) read 200 points. Galt et al. (1968) indicated that 400 points were inadequate for estimating the composition of the diet samples at the $5 \%$ confidence level. They illustrated that the accuracy of the estimation of the sample mean increased with increased sample intensity, but that the improvement was gradual.

In this study 200 points were identified in the esophageal samples. The first 100 points were recorded and then the tray was rotated $90^{\circ}$ and a second 100 points recorded. The agreement between the first and second 100 points was very good (Table 1). There were no significant $(P>$ $.05)$ differences in the proportion of plants identified when the two groups were comparcd. Consequently, the botanical composition of the rumen samples was estimated with the identification of 100 points. 
Table 1. Composition (\%) of duplicate esophageal samples.

\begin{tabular}{|c|c|c|}
\hline \multirow[b]{2}{*}{ Forage species } & \multicolumn{2}{|c|}{ Means $^{1}$} \\
\hline & $\begin{array}{c}\text { First } \\
100 \mathrm{pts} .\end{array}$ & $\begin{array}{l}\text { Second } \\
100 \text { pts. }\end{array}$ \\
\hline $\begin{array}{l}\text { Thickspike wheatgrass } \\
\text { (Agropyron dasystachyum) }\end{array}$ & 10 & 12 \\
\hline Crested wheatgrass & 14 & 12 \\
\hline Western wheatgrass & 10 & 11 \\
\hline $\begin{array}{l}\text { Pubescent western wheatgrass } \\
\text { (Agropyron smithii mólle) }\end{array}$ & 3 & 2 \\
\hline Blue grama & 2 & 2 \\
\hline Smooth bromc & 11 & 10 \\
\hline Prairie junegrass & 9 & 9 \\
\hline $\begin{array}{l}\text { Indian ricegrass } \\
\quad \text { (Oryzopsis hymenoides) }\end{array}$ & 2 & 3 \\
\hline Sandberg bluegrass & 4 & 4 \\
\hline $\begin{array}{l}\text { Needleandthread } \\
\quad(\text { Stipa comata })\end{array}$ & 15 & 14 \\
\hline Sedge spp. ${ }^{2}$ & 2 & 2 \\
\hline Grass Total & $\overline{82}$ & 81 \\
\hline Missouri vetch & 4 & 3 \\
\hline Striated vetch & 3 & 3 \\
\hline Foothill bladderpod & 4 & 4 \\
\hline Lewis flax & 0 & $<1$ \\
\hline Scarlet globemallow & 4 & 5 \\
\hline Forb Total & 15 & 15 \\
\hline Fringed sagewort & 2 & 2 \\
\hline Nuttall saltbush & 0 & $<1$ \\
\hline Rubber rabbitbrush & $<1$ & $<1$ \\
\hline Douglas rabbitbrush & $<1$ & $<1$ \\
\hline Winterfat & $<1$ & $<1$ \\
\hline $\begin{array}{l}\text { Squarestem phlox } \\
\text { (Phlox bryoides) }\end{array}$ & $<1$ & $<1$ \\
\hline Shrub Total & 3 & 4 \\
\hline Parmelia mollinscula & $<1$ & $<1$ \\
\hline Lichen Total & $<1$ & $<1$ \\
\hline Total & 100 & 100 \\
\hline
\end{tabular}

${ }^{1}$ Based on 18 samples.

${ }^{2}$ Not grass species but considered with this group for convenience.

Esophageal vs. Rumen Samples

\section{Botanical Data.}

The botanical analyses of rumen and esophageal samples are shown in Table 2. Rumen samples had a significantly higher proportion of grass species than esophageal samples. Six of the 11 individual grass species were present in higher proportions in the rumen samples. Conversely, there was a significantly lower proportion of forbs and shrubs present in rumen samples. The botanical composition of rumen grab samples was different from esophageal samples. This could be due to a differential rate of rumen digestion of different species of plants. It is also possible that a layering of rumen contents occurred whereby grass species were more likely to float to the top in the rumen
Table 2. Composition (\%) comparison of rumen and esophageal samples.

\begin{tabular}{|c|c|c|}
\hline \multirow[b]{2}{*}{ Forage species } & \multicolumn{2}{|c|}{ Means ${ }^{1}$} \\
\hline & $\begin{array}{l}\text { Rumen } \\
\text { sample }\end{array}$ & $\begin{array}{c}\text { Esophageal } \\
\text { sample }^{2}\end{array}$ \\
\hline $\begin{array}{l}\text { Thickspike wheatgrass } \\
\text { (Agropyron dasystachyum) }\end{array}$ & $15^{*}$ & 10 \\
\hline Crested wheatgrass & 18 & 14 \\
\hline Western wheatgrass & 11 & 10 \\
\hline $\begin{array}{l}\text { Pubescent western wheatgrass } \\
\text { (Agropyron smithii mólle) }\end{array}$ & 3 & 3 \\
\hline Blue grama & $5^{*}$ & 2 \\
\hline Smooth brome & 11 & 11 \\
\hline Prairie junegrass & $7 *$ & 9 \\
\hline $\begin{array}{l}\text { Indian ricegrass } \\
\quad \text { (Oryzopsis hymenoides) }\end{array}$ & $3^{*}$ & 2 \\
\hline Sandberg bluegrass & $6^{*}$ & 4 \\
\hline $\begin{array}{l}\text { Needleandthread } \\
\quad(\text { Stipa comata })\end{array}$ & 14 & 15 \\
\hline Sedge spp. ${ }^{3}$ & 2 & 2 \\
\hline Grass Total & $95 *$ & 82 \\
\hline Missouri vetch & $<1^{*}$ & 4 \\
\hline Striated vetch & $<1^{*}$ & 3 \\
\hline Foothill bladderpod & $<1^{*}$ & 4 \\
\hline Lewis flax & 0 & 0 \\
\hline Scarlet globemallow & 2 & 3 \\
\hline Forb Total & $4^{*}$ & 14 \\
\hline Fringed sagewort & $<\mathrm{l}^{*}$ & 1 \\
\hline Nuttall saltbush & 0 & 0 \\
\hline Rubber rabbitbrush & 0 & $<1$ \\
\hline Douglas rabbitbrush & $<1$ & 1 \\
\hline Winterfat & 0 & $<1$ \\
\hline $\begin{array}{l}\text { Squarestem phlox } \\
\text { (Phlox bryoides) }\end{array}$ & 0 & $<1$ \\
\hline Shrub Total & $1^{*}$ & 4 \\
\hline Parmelia mollinscula & 0 & $<1$ \\
\hline Lichen Total & 0 & 0 \\
\hline Total & 100 & 100 \\
\hline
\end{tabular}

1 Based on 17 samples.

${ }^{2}$ Values of first reading.

${ }^{3}$ Not grass species but considered with this group for convenience.

* Rumen samples significantly different $(P<.05)$ from esophageal samples.

than shrubs or forbs. If the esophageal sample can be considered as the standard of comparison, it must be concluded that sampling via a rumen fistula grab sample will lead to erroneous results in the proportion of botanical species found in the diet.

A seasonal trend was exhibited when the proportion of grass species was graphed relative to time 


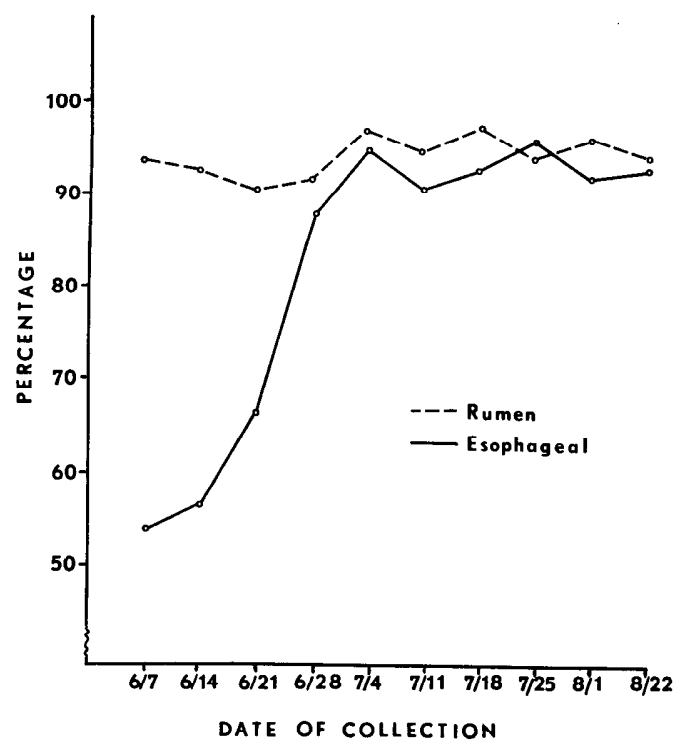

FIG. 1. Total percent of grass species in rumen and csophagcal samples versus date of collection.

of sampling (Fig. 1). There was a wide difference in the proportion of grass species found in rumen versus esophageal samples for the first three sampling dates. Subsequent to this time there was relatively little difference in the proportion of grasses found by the two sampling methods.

The opposite trend was found relative to the proportion of forb species in rumen and esophageal samples. For the first three sampling dates, forbs made up a much greater proportion of the esophageal sample than of the rumen sample (Fig. 2). Shrubs made up a minor proportion of the diet by both sampling methods but tended to be higher in esophageal than in rumen samples especially early in the grazing period (Fig. 3).

During the early part of the grazing season forbs were in a green growing stage. At this time they

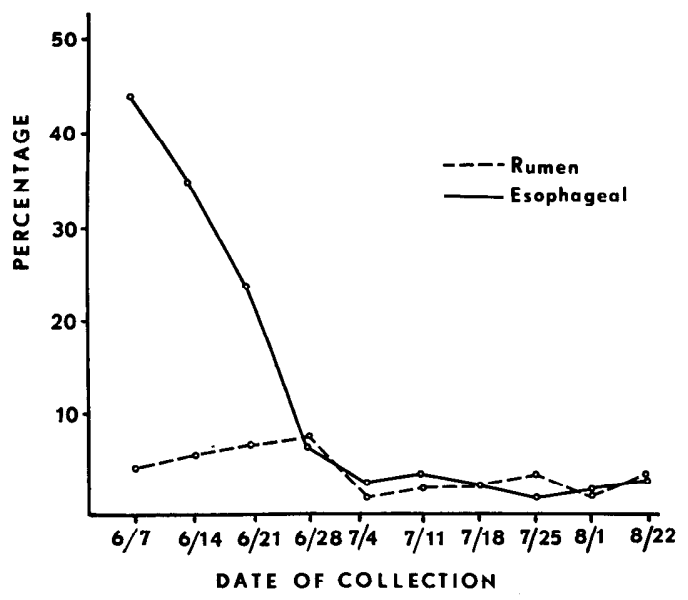

Fig. 2. Total percent of forb species in rumen and esophageal samples versus date of collection.

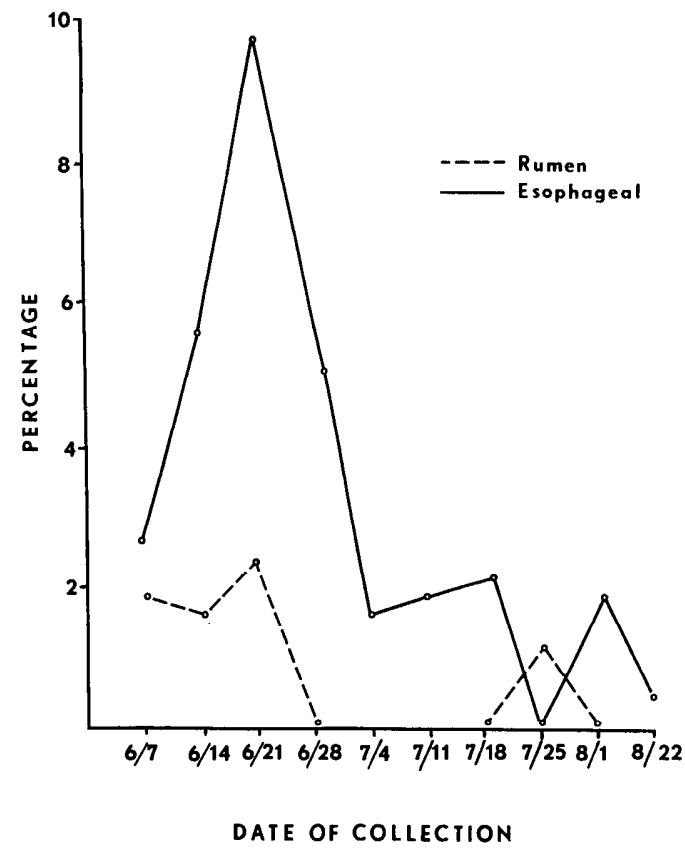

FIG. 3. Total percent of shrub species in rumen and esophageal samples vcrsus date of collection.

would be expected to have the highest digestibility and supposedly the most rapid rate of digestibility. The preferential rumen digestion of forbs relative to grass would make rumen samples higher in proportion of grasses than esophageal samples which had not been subjected to rumen digestion.

The rumen sampling technique does note the presence or absence of plant species in ruminant diets, but cannot be used to express quantitative relationships among plant species grazed where considerable variety is possible in the diet. Differential digestion leads to low estimates of highly digestible plants in rumen samples.

\section{Chemical Data.}

The nitrogen content of esophageal samples was less than rumen samples for all but the earliest sampling date (Fig. 4). This would be expected since the contribution of rumen microflora and microbial activity would tend to compensate for declining nitrogen in the diet as the grazing season progressed. There was a steady decline in the nitrogen content of esophageal samples, reflecting the changing botanical composition of the diet as well as a decline in the nitrogen content of the plants with advancing maturity. The shift towards more grass species in the diet (Fig. 1) and more mature plants eaten would result in lower nitrogen value. The decline in nitrogen was not so pronounced with the rumen sample. This was probably due to the contribution of rumen microflora to the total nitrogen found in rumen samples. 


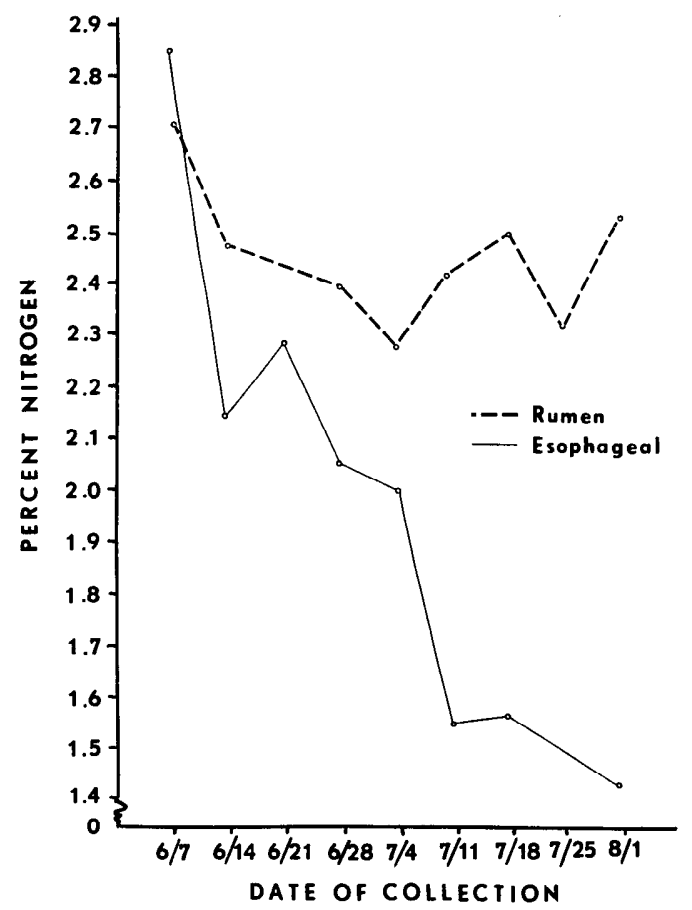

Fig. 4. Nitrogen content of rumen and esophageal samples versus date of collection.

\section{Digestibility.}

The esophageal samples were higher in in vitro digestibility than rumen samples (Fig. 5). There was a tendency for esophageal samples to have a constant digestibility throughout the grazing season. This illustrates the ability of sheep grazing mixed vegetation to select plant species which were digestible. The animal apparently sclected plant portions which were highly digestible thus maintaining a rather constant dry matter digestibility. If the grazing season had extended into fall where all plants had reached a mature stage the digestibility of the dict would be expected to declinc. The lower digestibility of rumen samples is undoubtedly due to the action of rumen microflora on ingested plants. They probably made use of the readily digestible portions of plants rapidly. The material remaining in the rumen at sampling represented partially digested plant material. There was a more pronounced seasonal decline in the digestibility of rumen samples than esophageal samples. The decline was probably related to more mature plants and the accumulation of slowly digested residues as the maturity of the diet increased.

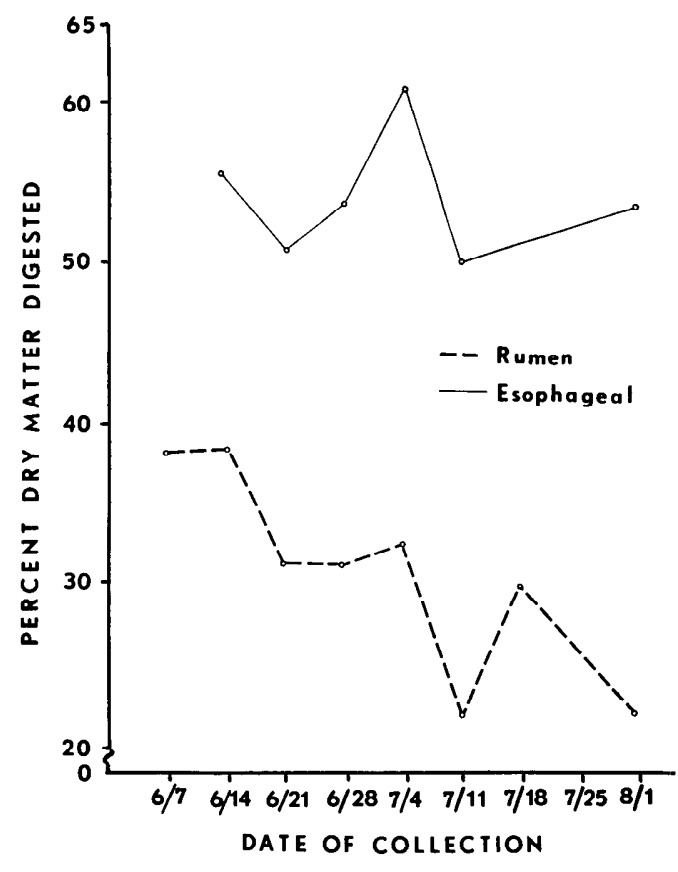

Fig. 5. In vitro dry matter digestibility values of rumen and esophageal samples versus date of collection.

\section{Literature Cited}

AOAC. 1960. Official methods of analysis (9th. ed.) Assoc. of Official Agr. Chemists., Wash., D. C. 832 p.

Galt, H. D., R. R. Ogden, J. H. Ehrenreich, B. Theurer, AND S. C. Martin. 1968. Estimation botanical composition of forage samples from fistulated steers by a microscopic point method. J. Range Manage. 21:391401.

Harker, K. W., D. T. Torell, and G. M. Van Dyne. 1964. Botanical examination of forage from esophageal fistulas in cattlc. J. Anim. Sci. 23:468-469.

Lesperance, A. L., V. R. Bohman, and D. W. Marble. 1960. Development of techniques for evaluating grazed forage. J. Dairy Sci. 43:682-689.

Martin, A. C., AND L. J. Korschgen. 1963. Food habits procedures. Wildlife Investigational Techniques. The Wildlife Soc., Wash., D. C. p. 320-333.

Tilley, J. M. A., And R. A. Terry. 1963. A two-stage technique for the in vitro digestion of forage crops. J. British Grassland Soc. 18:104-111.

Van Dynf, G. M., and H. F. Heady. 1965. Botanical composition of sheep and cattle diets on a mature animal range. Hilgardia 36:465-492.

Van Dyne, G. M., ANd D. T. Torell. 1964. Development and use of the esophageal fistula. J. Range Manage 17:7-17. 